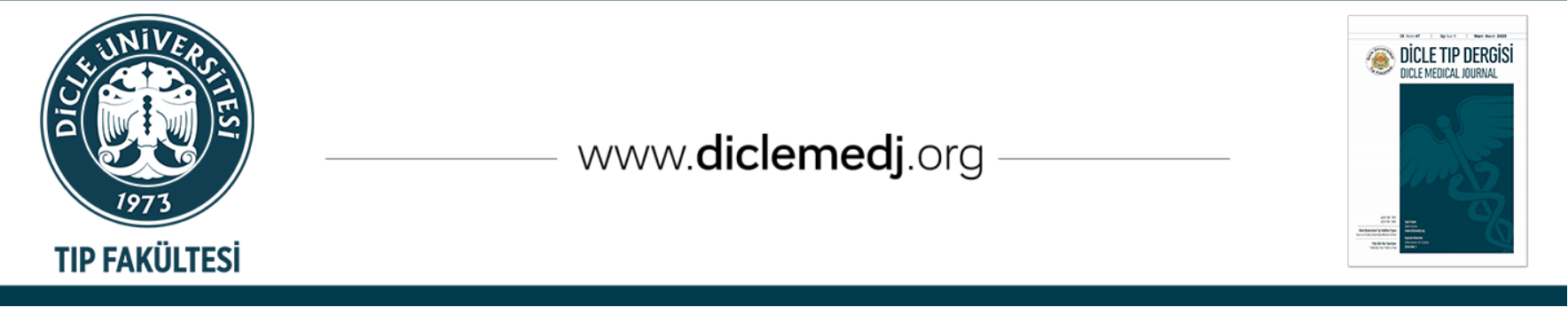

Original Article / Özgün Araştırma

\title{
The Frequency of Non-Epileptic Seizures in Epileptic Patients, the Relationship with Anxiety and Depression
}

\author{
R.Gokcen Gozubatik-Celik ${ }^{1}{ }_{1}$, Mecbure Nalbantoglu ${ }^{D}{ }_{2}$, Mesrure Koseoglu ${ }^{D}{ }_{1}$, Muazzez Gokcen Karahan (D) 1 , \\ Ayten Ceyhan Dirican iD1, Dilek Ataklı iD1 \\ 1 Department of Neurology, Bakirkoy Training and Research Hospital for Psychiatry and Neurological Disorders, University of Health Sciences, Istanbul, \\ Turkey
}

2 Department of Neurology, Bilim University Faculty of Medicine, Istanbul, Turkey

Received: 09.03.2020; Revised: 05.05.2020; Accepted: 10.05.2020

\begin{abstract}
Objective: In this study, psychogenic-nonepileptic seizure (PNES) frequency was investigated in epileptic patients; we explored the association between the disease duration, population / clinical data and the prevalence of depression fear.

Method: The study included 108 patients with definitive epilepsy. Video EEG and medical records were treated for PNES in patients. Demographic features, duration of illness, seizure frequency, type of seizures, all treatments have been documented. All patients earned the Beck Depression and Anxiety Scale. Patients were divided into two groups along with epileptic (Group1) and PNES (Group2). Patients were divided into two groups.

Results: The mean age of the patients was $48 \pm 12.31$ years. Fifty-six of all patients $(51.8 \%)$ were female. Psychiatricnonepileptic-seizures had been shown in 41(37.9\%) of 108 epileptic patients.25 of 41 patients (60.9\%) were female. Of the 41 patients with non-epileptic seizures, $23(56 \%)$ were observed to have epileptic seizures under control. Depression and anxiety scores were significantly higher in Group 2 compared to Group $1(\mathrm{p} \leq 0.005)$.
\end{abstract}

Conclusion: In patients with long-term and depressed/anxiety symptoms, PNES should be challenged, particularly in the presence of various forms of seizures treatment resistance, even under control.

Keywords: anxiety, depression, epileptic seizure, non-epileptic psychiatric seizure

DOI: 10.5798/dicletip.755689

Correspondence / Yazışma Adresi: Rabia Gökçen Gözübatık Çelik, Department of Neurology, Bakirkoy Training and Research Hospital for Psychiatry and Neurological Disorders, University of Health Sciences, Istanbul, Turkey e-mail: gokcen3@hotmail.com 


\section{Epilepside Non-Epileptik Nöbet Sıklığı, Anksiyete ve Depresyonla İlişkisi}

\section{Öz}

Amaç: Bu çalışmada epilepsi hastalarında psikojenik-nonepileptik-nöbet (PNES) sıklığını araştırmayı; hastalı̆ı̆n süresi, demografik / klinik veriler ile depresyon anksiyete varlığı arasındaki ilişkiyi araștırmayı amaçladık.

Yöntemler: Kesin epilepsi tanılı 108 hasta prospektif olarak çalışmaya dahil edildi. Hastalardaki PNES'lere video EEG ve hasta kayıtları değerlendirilerek tanı konuldu. Demografik özellikler, hastalık süresi, nöbet sıklığı, nöbet tipleri, tedavilerin tümü kaydedildi. Tüm hastalara Beck Depresyon ve Anksiyete Skalası uygulandı. Hastalar sadece epileptik nöbet geçirenler (Grup 1), PNES de eşlik edenler olarak iki gruba ayrıldı (Grup 2).

Bulgular: Hastaların yaş ortalaması $48 \pm 12.31$ yıldı. Hastaların 50'sini $(\% 51,8)$ kadındı. Epileptik nöbet geçiren 108 epileptik hastanın 41 'inde $(\% 37,9)$ PNES izlendi; 41 hastanın 25'i $(\% 60,9)$ kadındı. Non-epileptik nöbet geçiren 41 hastanın 23'ünde (\%56) epilepsi

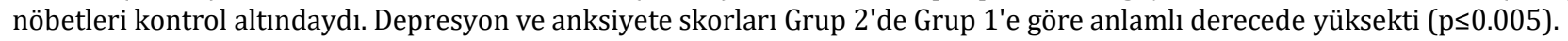

Tartışma: Uzun süreli ve depresif/anksiyöz semptomları olan hastalarda, özellikle farklı tipte nöbet veya tedaviye direnç varlığında nöbetler kontrol altında bile olsa PNES sorgulanmalıdır.

Anahtar kelimeler: Anksiyete, depresyon, epileptik nöbetler, non-epileptik psikiyatrik nöbetler.

\section{INTRODUCTION}

Epilepsy is a chronic neurologic disease which has neurobiological, cognitive, psychological and social effects and is common in all countries $^{1}$. Epilepsy is the second most common neurological disorder in our country among adults with a prevalence of approximately 0.4-1 percent ${ }^{2}$. Epilepsy diagnosis is difficult because it relies primarily on the history of patients and eyewitnesses. Diagnosis is made by evaluating anamnesis taken from all relatives and themselves who have seen similar seizures, self and family characteristics, neurological examination, imaging methods and electrophysiological findings (routine EEG, video EEG).

Differential types of seizures and neurological disorders include some disorders. There are several diseases. Two distinctions as physiological and psychogenic non-epileptic seizure (PNES) can be split into non-epileptic seizures. Although the literature takes account of the properties listed in the study (seizures, electrophysiological tests, levels of blood prolactin etc.), the physicians have also had problems because there is no clear sensitivity to the test to separate epileptical and non-epileptic seizures $^{2}$. The proportion of anti-epileptic medications used in this sense is $25 \% \%^{4}, 5$. Non epileptic psychogenic seizures can be defined as the reflections of psychiatric events ${ }^{6}$. Its population prevalence varies from $1 / 3000$ to $1 / 50000$. Furthermore, PNES can be seen in teenagers and children as well in women aged 30-40 years ${ }^{5}$.

Epilepsy and PNES can also coexist. Concurrent epilepsy is also seen in patients with PNES and diagnosis process can be complicated. The percentage of PNES patients with coexisting epilepsy varies from $3.6 \%$ to $58 \%$ in different studies $^{7-11}$. The diagnosis of PNES is often delayed by a decade or more. During this interval, patients undergo many evaluations and are likely to experience iatrogenic injury from drug poisoning, pseudo-state epileptic intubation, and seldom even implantation or epilepsy surgery ${ }^{12}$. In one study, PNES was estimated to be between 17-30 percent of patients referred to tertiary treatment centers with a drug resistant epilepsy diagnosis ${ }^{13}$. No measures or findings that have reliability or relevance in the treatment of PNES are currently available ${ }^{14,15}$. Epilepsy patients are often affected by especially drug resistant epilepsy. In another study conducted in our 
country, comorbid illness levels are estimated to be 32 percent with epilepsy, and depression and anxiety disorders are the two most common psychiatric comorbidities in these patients. In PNES cases, anxiety and depression levels are usually higher than people with epilepsy ${ }^{16,17}$.

In this context, we aimed to investigate the frequency of PNES in patient definite diagnosis of epilepsy and to investigate the relationship between PNES with the type of diagnosis, duration of the disease, demographic/ clinical data and depression and anxiety level.

\section{METHODS}

108 of the 975 patients with non-epileptic seizures who came to our outpatient clinic with a complaint of seizures within 2 years and who were diagnosed with definitive epilepsy (new and/or old diagnosed), according to ILAE criteria were included in this cross-sectional prospective study between January 2016 and December 2018. The medical consent form was filled out to all participants. patients over 18 years of age and diagnosed with epilepsy were included on a voluntary basis. patients with severe psychiatric disorders such as mental retardation or those with previously known/diagnosed psychiatric illness, encephalomalacia, tumor, stroke (ischemic/haemorrhagic), metabolic disease seizures were excluded, while symptomatic with hippocampal sclerosis and focal cortical dysplasia. Video EEG (VEEG) monitoring was performed to diagnosis of epilepsy in all 108 patients. Also, the presence of PNES in 101 patients was detected by VEEG monitoring, while 15 patients were identified by their preand post-seizure findings recorded from both their mobile phones and routine EEG findings more than once records. Seven patients were diagnosed with anamnesis from themselves and their relatives, clinical and routine EEG findings suggesting non-epileptic seizures. In addition, PNES was identified as lack of epileptiform activity in routine EEG or/and Video EEG during these attacks. Demographic characteristics, duration of the disease, frequency of seizure, types of seizure and treatments were all recorded. Beck Depression and Beck Anxiety Scales were used to all patients during the study. Patients were divided into two groups with only epileptic seizures (Group 1) and those with epileptic seizures accompanied by PNES (Group 2). In patients with PNES, epileptic seizures were considered to have concomitant epilepsy when caught with VEEG, when interictal epileptiform activity was recorded, or when past clinical and electrographic data confirmed epilepsy. Patients with previously known psychiatric disease in the anamnesis, and with irregular drug use were excluded.

Beck Depression Inventory (BDI): This It is a 21item self-assessment scale of 21-item that tests characteristic behaviour and symptoms of depression. 10-18 points mean as mild depression symptom, 19-29 points show suggest moderate depression, 30-63 points show the sign of severe depression

Beck Anxiety Inventory (BAI): There are questions as to whether a person has encountered the conditions mentioned in the last week and the extent to which 21 questions have been raised. Composed of 21 questions, the conditions mentioned in the last week have been experienced and what is to be extended. 815 points indicates a mild anxiety,16-25 is as moderate anxiety the outcome is extreme anxiety between $26-35$ points in the individual.

SPSS-18 was used for statistical evaluation. Groups were compared with univariate analysis, using Fisher's exact test and Chi-square (noncontinuous variables) or independent samples ttest (continuous variables). Statistical significance $\mathrm{p}<0.05$ was acknowledged in all analyses. Our study was approved by the ethics committee of our hospital (07.07.2019 number: 306) 


\section{RESULTS}

A total of 108 epilepsy patients were included in the study.

The mean age of the patients was $48 \pm 12.31$ (min:18, max:59) years. 56 of all patients (51.8\%) were female. Seventy three of 108 patients (67.5\%) were diagnosed with genetic (idiopathic) epilepsy, 8 of them were symptomatic (mesial temporal sclerosis, focal cortical dysplasia) epilepsy, and 27 of them had unknown etiology. 73 patients represented generalized seizures, 28 patients had secondary generalized seizures and 26 patients described focal motor seizures. The mean disease duration was $9.8 \pm 4.2$ years (min, max: 6 months-28 years). $36 \%$ of the patients had high school graduation (Table I).

Table I: Demographic and Clinical features of all patients

\begin{tabular}{|c|c|c|}
\hline \multicolumn{2}{|c|}{ Patients [n:108] } & Features \\
\hline \multicolumn{2}{|c|}{ Women/Men [n][\%] } & $56 / 52[51,8 / 48,1]$ \\
\hline \multicolumn{2}{|c|}{ The Mean age/years [min-max] } & $48 \pm 12,31[18-59]$ \\
\hline \multirow{3}{*}{$\begin{array}{c}\text { Type of epilepsy } \\
{[\mathrm{n}][\%]}\end{array}$} & $\begin{array}{l}\text { idiopathic } \\
\text { generalized epilepsy }\end{array}$ & $73(67.6)$ \\
\hline & $\begin{array}{l}\text { symptomatic } \\
\text { epilepsy }\end{array}$ & $27(25)$ \\
\hline & $\begin{array}{l}\text { epilepsy with } \\
\text { unknown etiology }\end{array}$ & $8(7.4)$ \\
\hline \multirow{3}{*}{$\begin{array}{l}\text { Type of seizure } \\
{[\mathrm{n}][\%]}\end{array}$} & focal seizures & $26(24)$ \\
\hline & $\begin{array}{l}\text { seconder } \\
\text { generalized seizures }\end{array}$ & $28(25.9)$ \\
\hline & generalized seizures & $73(67.6)$ \\
\hline \multicolumn{2}{|c|}{ The Mean Disease Duration } & $\begin{array}{l}9.8 \pm 4.2 \text { years }[6 \\
\text { month- } 28 \text { years] }\end{array}$ \\
\hline \multirow{2}{*}{ Education[n][\%] } & More than 11 years & $39[36.1]$ \\
\hline & less than 11 years & $69[63.8]$ \\
\hline
\end{tabular}

From all of the patients $72(66.6 \%)$ of them were under monotherapy and 36 (33.3\%) were under polytherapy (Table II).

PNES had been shown with epileptic seizures in 41 (37.9\%) of 108 epileptic patients. Thus, 25 of 41 patients $(60.9 \%)$ were women.

None of the patients had a history of suspicion of PNES prior to the diagnosis of epilepsy. No significant relationship was found between the level of education and PNES ( $p=0.143)$. When the seizure type and PNES presence were compared, no significant correlation was observed additively ( $\mathrm{p}=0.274)$.

Table II: Demographic and Clinical features of patients according to groups

\begin{tabular}{|c|c|c|c|c|}
\hline \multicolumn{2}{|c|}{ Groups } & $\begin{array}{l}\text { Having } \\
\text { Only } \\
\text { Epileptic } \\
\text { Seizures } \\
\end{array}$ & $\begin{array}{l}\text { Having } \\
\text { PNES with } \\
\text { Epileptic } \\
\text { Seizures }\end{array}$ & $\begin{array}{l}P \\
\text { value }\end{array}$ \\
\hline \multicolumn{2}{|c|}{ Patients [n] (\%) } & $67(62.0)$ & $41(38.0)$ & 0.218 \\
\hline \multicolumn{2}{|c|}{$\begin{array}{c}\text { The Mean Age/years } \\
\text { [min-max] }\end{array}$} & $\begin{array}{l}47 \pm 11.36[1 \\
8-59]\end{array}$ & $\begin{array}{l}51 \pm 11.50[1 \\
9-57]\end{array}$ & 0.195 \\
\hline \multirow{3}{*}{$\begin{array}{l}\text { Type of } \\
\text { epilepsy } \\
{[n](\%)}\end{array}$} & $\begin{array}{l}\text { idiopathic } \\
\text { generalized } \\
\text { epilepsy[n] }\end{array}$ & $43(64.1)$ & 30 (73.1) & 0.103 \\
\hline & $\begin{array}{l}\text { symptomati } \\
\text { c } \\
\text { epilepsy[n] }\end{array}$ & $17(25.3)$ & $10(24.3)$ & 0.176 \\
\hline & $\begin{array}{l}\text { epilepsy } \\
\text { with } \\
\text { unknown } \\
\text { etiology [n] }\end{array}$ & $4(5.9)$ & $4(9.7)$ & 0.095 \\
\hline \multirow{3}{*}{$\begin{array}{l}\text { Type of } \\
\text { seizure } \\
{[n](\%)}\end{array}$} & $\begin{array}{l}\text { focal } \\
\text { seizures } \\
\text { [simple / } \\
\text { complex] } \\
{[\mathrm{n}]}\end{array}$ & $15(22.3)$ & $11(26.8)$ & 0.094 \\
\hline & $\begin{array}{l}\text { seconder } \\
\text { generalized } \\
\text { seizures [n] }\end{array}$ & $16(23.8)$ & $12(29.2)$ & 0.147 \\
\hline & $\begin{array}{l}\text { generalized } \\
\text { seizures [n] }\end{array}$ & $43(64.1)$ & $30(73.1)$ & 0.089 \\
\hline \multicolumn{2}{|c|}{$\begin{array}{c}* \text { The Mean Age of } \\
\text { Disease Duration [years] }\end{array}$} & $7.68 \pm 2.4$ & $12,09 \pm 1.2$ & $\begin{array}{l}\mathbf{0 . 0 0 2} \\
*\end{array}$ \\
\hline \multicolumn{2}{|c|}{$\begin{array}{c}* \text { The Number of } \\
\text { Epileptic Seizures } \\
\text { [units/year] [min-max] }\end{array}$} & $4[1-8]$ & $1.5[0-2]$ & $\begin{array}{l}\mathbf{0 . 0 0 1} \\
*\end{array}$ \\
\hline \multirow{2}{*}{$\begin{array}{c}\text { Treatme } \\
\text { nt }[\mathrm{n}] \\
(\%)\end{array}$} & $\begin{array}{l}\text { monothera } \\
\text { py }\end{array}$ & $55(82.0)$ & $17(41.5)$ & \multirow{2}{*}{$\begin{array}{l}\mathbf{0 . 0 0 1} \\
*\end{array}$} \\
\hline & $\begin{array}{l}\text { polytherap } \\
\text { y }\end{array}$ & $12(18.0)$ & $24(58.5)$ & \\
\hline
\end{tabular}

Of the 41 patients with non-epileptic seizures, 23 (56\%) were observed to have epileptic seizures under control (last one-year seizure free). It was noted that epilepsy was longer in patients with psychiatric seizures and the frequency of epileptic seizures was lower than in others significantly. ( $p=0.002)$ (Table II).

The rate of PNES was found higher in patients under polytherapy than in those receiving monotherapy significantly. $(\mathrm{p}=0.001)$.

When both groups evaluated according to depression and anxiety scores; depression and anxiety scores were significantly higher in 
Group 2 compared to Group 1 ( $p=0.000$, $\mathrm{p}=0.018$ respectively). (Table III).

Table III: Beck Depression and Anxiety Scores of Patients

\begin{tabular}{|c|l|l|l|l|}
\hline \multicolumn{2}{|c|}{ Scales } & $\begin{array}{l}\text { Group1 } \\
\text { (\%)(n) }\end{array}$ & $\begin{array}{l}\text { Group } \\
\text { (\%)(n) }\end{array}$ & P value \\
\hline \multirow{2}{*}{$\begin{array}{c}\text { Beck Depression Score } \\
\text { (min-max:0-63) }\end{array}$} & $<18$ & $75.1(50)$ & $26.9(11)$ & \multirow{2}{*}{$* 0.000$} \\
\cline { 2 - 4 } $\begin{array}{c}\text { Beck Anxiety Score } \\
\text { (min-max:0-63) }\end{array}$ & $<18$ & $24.9(17)$ & $73.1(31)$ & \\
\cline { 2 - 4 } & $\geq 16$ & $31.1(21)$ & $27.1(11)$ & \multirow{2}{*}{$* 0.018$} \\
\hline
\end{tabular}

After all, in Group 2, 11 (26.8\%) of 41 patients with mixed type seizures, the PNES were evaluated as epileptic seizures by Neurologist or Emergency Physician in other centers', and the antiepileptic treatments of patients were intervened (as adding new antiepileptic drugs or increasing current treatment dose). However, at follow-up, 8 of 11 patients reported that the frequency of seizures did not change with these changes on their treatments.

\section{DISCUSSION}

The first step is to assess if the clinical image is an epileptic seizure in the assessment of patients for seismic conditions ${ }^{18}$. The original scientific assumption is based on the history and analysis of electroencephalography ${ }^{11}$. Any attacks of the epileptic patient should be examined and PNES should be held in mind following diagnosis. The gold standard for PNES distinction from epileptic seizures continues to be continuous VEEG. Comorbid conditions in epileptic patients were shown to be 8 times more common relative to the general population in literature. It affects life peace and consistency ${ }^{21}$ For example, in $70 \%$ of epileptic cases, 2 or more psychiatric conditions are diagnosed simultaneously ${ }^{22}$. In Leppan's other prospective study, the neurologist was able to predict epileptic seizures with 87 percent of 158 patients. Yet the diagnosis of epileptic seizure had improved for one case after EEG recording ${ }^{23}$. All PNES patients were examined and no epileptic activity was observed in EEG during their attack. Semiological observations for PNES were also found in many of them. PNES patients with coexisting epilepsy range from 3.6 percent to 58 percent in various studies ${ }^{7-11}$. Psychiatric conditions tend to be at least 2-3 times higher in epilepsy patients than in general population. For one study, depression prevalence for patients with epilepsy was $23.1 \%$, anxiety $22.8 \%$, interictal psychosis 5.2 $7 \%$, personality disorders $4-38 \%$, and suicide 5 $14.3 \%{ }^{19}$. By another study, comorbid associations between epilepsy and anxiety, depression, bipolar disorder, carelessness, and hyperactivity syndrome were reported ${ }^{20}$. Common mechanisms can play a role in epilepsy and comorbid conditions. Studies also found that psychological conditions such as anxiety and depression are more prevalent in patients with psychogenic seizures and have a higher history of suicidal involvement and psychological drug intake. Moreover, researchers found that patients with psychogenic seizures had lower survival rates, more frequent long-term health issues and more unstable family relationships than patients with epilepsy25. In a study of 77 patients with 45 PNES and 32 ES, FAD (McMaster Family Assessment Device), HRQOL (Health-related Quality of Life) and Beck Depression Survey (BDI-II) were applied. This study found that PNES patients increased depressive symptoms and substantially decreased quality of life ${ }^{14}$.

In our study, epilepsy diagnosis time was longer in PNES patients, and the incidence of epileptic seizures was lower. Simultaneously, as the length of the illness increased, patient depression ratings improved dramatically. Besides this relationship, the depression scores of PNES patients were found to be substantially higher than those without PNES. This finding was also important for PNES patient anxiety levels, although their anxiety levels were higher than patients without PNES. 
Twenty percent of patients diagnosed with drug-resistant epilepsy had psychogenic seizures ${ }^{21}$. Several studies have similar findings. In the Baburhan et al. video EEG monitoring analysis for seizure diagnosis, 31 out of 89 patients had nonepileptic psychogenic seizures. A research of patients of refractory epilepsy found $12.5 \%$ of PNES incidence 20 . In the literature, the prevalence of misdiagnosisrelated use of antiepileptic drugs (AED) is 25 percent ${ }^{5}$. PNES was extremely prevalent in epilepsy patients $(37.9 \%)$ in our study. As a result, PNES prevalence is higher than other research, as our hospital is one of the epilepsies centers' where serious seizure patients come from other hospitals. Last year, epileptic patients with PNES were found to be seizurefree and most were monotherapy-controlled (56\%) in addition. Therefore, due to misdiagnosis, patients should be properly tested to prevent inappropriate substance use.

Otherwise, individuals with epilepsy can have certain obstacles to their quality of life. Stigmatization due to certain mistaken assumptions, expectations and behaviors hinders the lives of people with epilepsy and adversely affects their quality of life. Such behaviors, which trigger social isolation, can bring additional conditions such as depression and anxiety, even though they control their seizures. For this research, psychiatry clinic followed up with PNES patients. For 60\%, additional psychiatric care was begun, $30 \%$ was recommended for psychotherapy, $10 \%$ did not recognize psychiatric control. Conclusion:

PNES in patients with refractory seizures may lead to diagnostic and therapeutic complications. Because of excessive antiepileptic drug use misdiagnosis as epileptic seizures instead of PNES may cause side effects and material burdens Undiagnosed patients use high emergency care inappropriate, costly treatments. Therefore, to determine the underlying causes of treatment resistance, epileptic patients should be closely investigated for PNES. Particularly, in patients with depressive and anxiety symptoms, if there is some form of new seizures or drug resistant seizure, PNES should be considered. Similarly, According to the study examining the perception of epilepsy in Turkey likewise fear, stigma, social isolation; epilepsy are important psychosocial health problems for individuals coping. To develop healthy practices in epilepsy, training may help to improve people's understanding and perception of the condition in particular it will be beneficial to increase the knowledge and awareness of the people especially about the disease by trainings. Our study also introduced the importance of multidisciplinary neurology-psychiatry approach in epileptic patients.

Clinical implications or Article Highlights

- The presence of PNES in patients with refractory seizures may lead to diagnostic and therapeutic complications.

- Misdiagnosis as epileptic seizures instead of PNES may cause side effects and material burdens due to unnecessary antiepileptic drug use.

- In patients with long-term and depressive symptoms especially, PNES should be considered if a different type of new seizures or drug resistant seizure is present.

Abbreviations:

ILAE: International League Against Epilepsy

PNES: Psychogenic Non-Epileptic Seizures

VEEG: Video Electroencephalography

AED: antiepileptic drugs

HRQOL: health-related quality of life

FAD: McMaster Family Assessment Device

BDI-II: Beck depression questionnaire II

Ethics Committee Approval: Statistical significance $p<0.05$ was acknowledged in all 
analyses. Our study was approved by the ethics committee of our hospital (07.07.2019 number:306)

Declaration of Conflicting Interests: The authors declare that they have no conflict of interest.

Financial Disclosure: No financial support was received.

\section{REFERENCES}

1. Yeni SN. Epilepsi Epidemiyolojisi. Turkiye Klinikleri J Neurol-Special Topics 1. 2008: 9-16.

2. Çakıl D, İnanır S, Baykan H, et al. Epilepsi ayırıcı tanısında psikojenik non-epileptik Nöbetler. Göztepe Tıp Dergisi. 2013; 28: 41-7.

3. Fisher RS, Acevedo C, Arzimanoglou A et al. ILAE official report: a practical clinical def-inition of epilepsy. Epilepsia. 2014; 55: 475-82.

4. Akdağ G, Algın DI, Erdinç OO. Epilepsi Osmangazi Journal of Medicine. 2016; 38: 35-41.

5. Lesser, R. P. Psychogenic seizures. Neurology, 1996; 46: 1499-507.

6. Bradley WG, Daroff RB, Fenichel GM, et al. Neurology in clinical practice (principles of diagnosis and manage $\neg$ ment) 4 th ed. Phledelphia 2004: 1971-2.

7. Reuber M, Qurishi A, Bauer J, et al. Are there physical risk factors for psychogenic non-epileptic seizures in patients with epilepsy? Seizure. 2003; 12: 561-7.

8. Benbadis SR, Agrawal V, Tatum WO. How many patients with psychogenic nonepileptic seizures also have epilepsy? Neurology. 2001; 57: 915-7.

9. Martin R, Burneo JG, Prasad A, et al. Frequency of epilepsy in patients with psychogenic seizures monitored by video EEG. Neurology. 2003; 61: 1791-2.

10. Chen-Block S, Abou-Khalil BW, Arain A, et al. Video-EEG results and clinical charac-teristics in patients with psychogenic nonepileptic spells: the effect of a coexistent epilepsy. Epilepsy Behav. 2016; 62: $62-5$.
11. El-Naggar H, Moloney P, Widdess-Walsh P, et al. Simultaneous occurrence of nonepileptic and epileptic seizures during a single period of inpatient video-electroencephalographic monitoring. Epilepsia Open. 2017; 2: 467-71.

12. Robbins NM,Larimer P, Bourgeois JA et al. Number of patient-reported allergies helps distinguish epilepsy from psychogenic non-epileptic spells (pseudoseizures). Epilepsy Behav. 2016; 55: 174-7.

13. Benbadis SR, Allen Hauser W. An estimate of the prevalence of psychogenic non-epileptic seizures. Seizure. 2000; 9: 280-1.

14. LaFrance WC, Alosco ML, Davis JD, et al. Impact of family functioning on quality of life in patients with psychogenic nonepileptic seizures versus epilepsy. Epilepsia. 2011; 52: 292-300.

15. MarcTesta S, Lesser RP, Krauss GL, et al. Personality Assessment Inventory among pa-tients with psychogenic sei zzures and those with epilepsy. Epilepsia. 2011; 52: 84-8.

16. Myers L, Trobliger $\mathrm{R}$, Bortnik $\mathrm{K}$, et al. Psychological trauma, somatization, dissociation, and psychiatric comorbidities in patients with psychogenic nonepileptic seizures compared with those in patients with intractable partial epilepsy. Epilepsy \& Behavior. 2019; 108-13.

17. Neze H, Havle N, Inem C, Yener F. Epilepsi Tanısı ile Takip Edilen Kişilerde Psikiyatrik Hastalıklar ve Bunun Yaşam Kalitesi Üzerine Etkisi New/Yeni Symposium Journal. 2009; 47: 147-54.

18. Bora S, Yeni S, Gürses N, Epilepsi. 1. Basım, Nobel Tip Kitabevleri, İstanbul. 2008; 707-34.

19. Josephson CB, Jette N. Psychiatric comorbidities in epilepsy. Int Rev Psychiatry. 2017; 29: 409-24.

20. Genç F, Yılmaz N, Biçer GY, et al. The Diagnostic and Prognostic Value of Induction Methods in Patients with Psychogenic Nonepileptic Seizures. Epilepsi. 2013; 19: 114-20. 
21. Keezer MR, Sisodiya SM, Sander JW. Comorbidities of epilepsy: current concepts and future perspectives. Lancet Neurol. 2016; 15: 10615.

22. Bowman ES, Markand ON. Psychodynamics and psychiatric diagnoses of pseudo-seizure subjects. Am J Psychiatry. 1996; 153: 57-63.

23. Angus-Leppan H. Diagnosing epilepsy in neurology clinics: a prospective study. Seizure. 2008; 17: 431-6.
24. Syed TU, LaFrance WC Jr, Kahriman ES, et al. Can semiology predict psychogenic nonepileptic seizures? A prospective study. Ann Neurol. 2011; 69: 997-1004.

25. Moore PM, Baker GA, McDade G, et al. Epilepsy, pseudoseizures and perceived family characteristics: a controlled study. Epilepsy Res. 1994; 18: 75-83. 